\title{
Totemism and Environmental Preservation among Nembe People in the South-South Zone, Nigeria
}

\author{
E. A. Sibiri PhD \\ Department of Sociology, Niger Delta University \\ Wilberforce Island, Bayelsa State, Nigeria \\ oyinkulesibiriyahoo.com
}

\section{Doi:10.5901/mjss.2014.v5n7p519}

\section{Abstract}

This study explored environmental indigenous practices that could promote environmental preservation among the people of Nembe in Bayelsa State. In spite of much concerns of both local and international bodies in the quest to preserve species in the environment, their efforts have not been fully successful in achieving such goals. Yet, measures to control species extinctions prove to no avail. In the view of this, alternative indigenous methods of species conservation in the environment must be advocated. The descriptive design was adopted, while theoretical triangulation of functionalism, symbolic interactionism and biocentrism were used as theoretical frameworks of analysis. 382 respondents participated in the study using the instruments of questionnaire as well as 5 key informants' interviewees (KII). Stratified random sample was employed for the selection of respondents as well as purposive sampling for the selection of key informants interviewees (KII) across the five communities (namely, Ogolomabiri, Basanbiri, Odeama, Okpoama and Brass) that constitutes the people of Nembe. Simple percentages and pie chart descriptive statistical tools were used for the analysis of the data collected for the study. Findings showed that totemism as an indigenous practice promotes species conservation which include python, eagle, shark, zimbaerema and snails with minimal threats or risks to the social environment. In the view of the findings of the study, policy instruments were provided in order to facilitate the design of environmental policies such as the establishment of zoos and game reserves, public enlightenment campaigns to encourage indigenous environmental practices across board as well as embarking on research in other indigenous practices that will promote environmental preservation and species conservatism.

Keywords: Ecosystem, environmental movement, environmental preservation, species' extinction, totemism

\section{Introduction and Background}

Right from the inception of the United Nations Environmental Programme (UNEP) in 1973, the central focus of much of its programmes has been efforts to co-ordinate issues related to the environment globally (Johns, 1992). Thus, it has also provided leadership and encouraged partnerships to care for the environment - for example, through Multilateral Environmental Agreements (MEAs) which have addressed issues such as species loss and the need for conservation at a global and regional level as well as formulation of international environmental laws which are in use in many countries today.

In line with this, United Nations Global Compact has drawn environmental principles from its Declaration of Principles and an International Action Plan (Agenda 21) which emerged from the United Nations Conference on Environment and Development (the Earth Summit) held in Rio de Janerio in 1992. Among others, the chapter 30 of its Agenda 21, identified that the policies and operations of business and industry can play a major role in reducing impacts on resource use and the environment (Jeremy and Isabelle, 2004; Johns, 1992).

In respect to series of environmental declarations and laws put in place by different international organizations and environmental unions, its compatibility to diverse cultural practices across the globe as well as effort to encourage indigenous methods of environmental preservation has not been given much attention globally.

From classical antiquity, whether from dreams or from physical nature, animism and naturism have attempted to construct the idea of the sacred out of the facts of our common and individual experience. As Durkheim (1912) asserted rival theories of religious origins thus led to his first positive conclusion: "Since neither man nor nature has of themselves a sacred character," he argued: They must get it from another source. Aside from the human individual and the physical world, there should be some other reality, in relation to which this variety of delirium which all religion is in a sense, has significance and an objective value. In other words, beyond those which we have called animistic and naturistic, there should be another sort of cult, more fundamental and more primitive, of which the first are, only derived forms or 
particular aspect (Durkheim, 1912).

For Durkheim however, this more fundamental and primitive cult is termed to as totemism, a system of belief in which each human is thought to have a spiritual connection or a kinship with another physical being, such as an animal or plant, often called a "spirit-being" or 'totem'. As Durkheim argued in his work on the study of totemism as practiced by Australian Aboriginal societies, totemism represent the religion in its most 'elementary' or simple form. It was originally an animal or plant taken as having particular symbolic significance for a group. It is sacred object, regarded with veneration and surrounded by various ritual activities. Sacred objects and symbols, he holds, are treated as apart from the routine aspects of existence, which are the realm of the profane (Giddens, 2001:537).

Against this background, it is apparent that though the practice of totemism by the indigenous people of its kinds may not have taken a concerted efforts to attach its much significance to the prevention of species' extinctions (animal or plant) which in turn stand to promote environmental conservation; yet its importance to avert indiscriminate killing, harm and eating up of totemic animals and plants among others which have no totemic values have considerably unveiled the significance of the practice to environmental preservation. In the view of this however, the study shall be made to focus on the practice of totemic belief among the Nembe people, who had from centuries specifically been involved in the practice of totemic beliefs such as python, zibaerema, shark, eagle and snails among other totemic organisms in the area.

\section{Statement of Problem}

According to the United Nations Document on species and ecosystems, species extinction has been a fact of life since life first emerged. The present few million species are the modern-day survivors of the estimated half-billion species that have ever existed. As such, almost all past extinctions have occurred by natural processes, but today human activities are overwhelmingly the main cause of extinctions as most of the species vanishing are those least documented, such as insects in tropical forests (Jeremy and Isabelle, 2004). Many species are losing whole populations at a rate that quickly reduces their genetic variability and thus leaving their ability to preserve and reproduce them for future generation to come thwarted.

Indeed, a plethora of environmental laws and charters have been put in place by the United Nations Environment Progrmmes (UNEP), the World Conservation Union (WCU), and United Nations Global Compact on the utilization of environmental resources among other environmental institutions to promote species conservation across board. Yet, its implementation and execution particularly at the grassroots (rural settlements) seem to be faced with difficulties. The laws and charters of which all member countries are signatories seem to pose serious challenges to the indigenous people in terms of unavailability of resources to implement at their levels, incompatibility of the laws and charters to their immediate environment as well as poor monitoring strategies on the parts of the international bodies that put them in place.

In this however, the loss of biodiversity, damage to species and their respective ecosystems have been on increase over years without looking inward to exploit the rich cultural practices that can stand the gaps. Nevertheless, this study explores the practice of totemic beliefs among Nembe people of Bayelsa State so as to reveal the much advantage that can be derived from the practice of totemism in the quest to promote environmental preservation.

\section{Objectives of the Study}

1. To examine the significance of totemic beliefs to species conservation among Nembe people.

2. To enlighten the people on the alternative indigenous practices that can promote environmental friendly practices.

3. To encourage cultural practices that will promote environmental conservation in Bayelsa State.

4. To give recommendations based on the findings of the study that will prevent species' extinction and the loss of biodiversity.

\section{Key Research Questions}

1. Does the practice of totemic belief prevent species' extinction among the people of Nembe?

2. Of what significance is totemic belief to environmental preservation among the people of Nembe?

3. Can the practice of totemism among the people of Nembe promote environmental preservation considering the influence of the western world environmental conservation practices? 
4. Considering the cultural diversities of Nigeria, how can the government and other relevant agencies on environmental issues provide alternative indigenous environmental practices that stand to promote environmental conservation?

\section{Theoretical Framework: Functionalism, Symbolic Interactionism and Biocentrism}

Functionalist perspective sees society as a complex system whose parts work together to promote solidarity, social order and stability (Macionis, 2010). The society is seen through a macro-level orientation, which is a broad focus on the social structures that shape society as a whole, and believes that society has evolved like organisms (DeRosso Deb, 2003). It attempts to look at both social structures and the functions of all elements therein in terms of norms, customs, traditions and institutions.

Herbert Spencer and Durkheim presented their own views of the society an organismic analogy and developed a view of human society as "organs or structure" made up of interrelated parts that work together for the proper functioning of the "body" as a whole. According to Spencer, just as the structural parts of the human body function interdependently to help the entire organism survive, social structures work together to preserve society (Urry, 2000; 1gbo, 2003).

Symbolic interactionism analyses the subjective meaning attached or imposed to symbols, objects, and events with respect to their interpretations which is peculiar to a group of people or society. It is in the belief that people behave based on what they believe and not just on what is objectively true. Thus, society is thought to be socially constructed through human interpretations of symbols. People interpret one another's behavior and it is these interpretations that form the social bond (Liadi, 2013; Meltzer, Petras \& Reynolds, 1975).

As Blumer (1939) and Charles (2005) argue symbolic interactionism has come into use as a label for a relatively distinctive approach to the study of human life and human conduct. With Symbolic interactionism, reality is seen as social, developed interaction with others. Most symbolic interactionists believe a physical reality does indeed exist by an individual's social definitions, and that social definitions do develop in part or relation to something "real." People thus do not respond to this reality directly, but rather to the social understanding of reality. Humans therefore exist in three realities: a physical objective reality, a social reality, and a unique reality (Charles, 2005; Liadi, 2013).

Biocentrism sees all life forms as 'moral patients'- entities to which we should accord moral consideration. We therefore have a duty towards all forms of life. As Schweitzer (1923) wrote:

The essence of goodness is to maintain and cherish life, and the essence of evil is to destroy and damage life. All living beings have the will to live, and all living beings with the will to live are sacred, interrelated and of equal value. It is, therefore, an ethical imperative for us to respect and help all life forms.

Taylor (1986) argues that all organisms are teleological centres of life, pursuing their own good in their own way. Taylor maintains that it is their telos (the Greek word for 'end', 'purpose' or 'goal') that gives each individual organism inherent worth, and that this worth is possessed equally by all living organisms because all individual living beings have a telos and a good of their own - a good as vital to them as a human good is to a human. The equal inherent worth of all living beings warrants according them equal moral status: therefore, we must respect all living organisms.

Attfield (1983) reaches the same conclusion from the approach of consequentialism and argued that an organism's ability to flourish and to exercise its basic capacities give it intrinsic value, for which we must extend moral consideration to it. Attfield's position is that an organism that has the ability to flourish and to develop has an interest in doing so, and that we have a duty to maximize the interests or utilities of any organism, regardless of its species (Attfield, 1983). In this respect, we have an obligation to care for the well-being of all living organisms in our environment.

\section{The Environment and Environmental Preservation}

The environment can be defined as the complex set of physical, geographic, biological, social, cultural and political conditions that surround an individual or organism and that ultimately determine its form and the nature of its survival. Conningham also defined environment as the circumstances and conditions that surround an organism or group of organisms or the social and cultural conditions that affect an individual or community. In this, the environment influences how people live and how societies develop. For that reason, people, progress, economic development and the environment are closely linked.

On the other hand, environmental protection (or preservation) is the practice of protecting the environment on individual, organizational or the government, for the benefit of the natural environment and as well as humans. Due to the 
pressures of population and technology, the biophysical environment is being degraded, sometimes permanently. Since the 1960's, activity of environmental movement has created much awareness of the various environmental issues. Thus, environmental protection is influenced by three interwoven factors which include environmental legislation, ethics and education. Each of these factors plays prominent roles in influencing national-level environmental decisions and personallevel environmental values and behaviors. For environmental protection to become a reality however, it is important for societies to develop each of these areas that, together, will inform and drive environmental decisions (Solomon, 2010).

\section{Understanding Totemism}

Haekel (2013) defined totemism as a system of belief in which humans are said to have kinship or mystical relationship with a spirit-being, such as animal or plant. However, an object of totem (animal or plant) is usually thought to interact with a given kin group or an individual which stand to serve as an emblem or a symbol to such group. It also involves the practice of having a natural object or animate being such as bird or animal as the emblem of a family, clan, or group. In regards to this, a totem is considered to play a significant role to those who accord much protective power of veneration and worship.

As Elkin (1954), Sylvio and Yahaya (2007) observed in their studies, there are key areas where totem can be significant to man and its environs (both social and physical environment). Firstly, the practice of totem serves as the emblem of a clan or family mystical or ritual bond of unity and solidarity.

Durkheim's work, The Elementary Forms of Religious Life, first published in 1912 has also illuminated the unveiling understanding of totemism as practiced by Australian Aboriginal societies. In his argument, totemism represents religion in its most 'elementary' or simple form. A totem was originally an animal or plant taken as having particular symbolic significance for a group. It is therefore a sacred object, regarded with veneration and surrounded by various ritual activities. However, sacred objects and symbols are treated as apart from the routine aspects of existence, which are the realm of the profane. Eating the totemic animal or plant except on special ceremonial occasions, is usually forbidden, and as a sacred object the totem is believed to have divine properties which separate it completely from other animals that might be hunted, or crops gathered and consumed (Giddens, 2001:537).exonerate

As Elkin (1938 [1954]: 133) maintained, totemism "is a view of nature and life, of the universe and man, which unites them with nature's activities and species in a bond of mutual life-giving". According to him, the terms 'totem' and 'totemism' convey three main meanings in New South Wales (NSW). The first is an identity meaning - the 'totem' is a non-human species or phenomenon that stands for, or represents, the group. The second is a relationship meaning - the 'totem' and the person or group share their physical substance, and share a kin relatedness. The third is a worldview meaning - the relationships are embedded in a view of the world in which connectivity is the foundation of all life.

Elkin (1938) rightly observed that there is ecological connectivity between man and totem. This is because a totemic species is not treated as if it were isolated from its environment. In other words, the duty of care that inheres in bonds of mutual life-giving includes human care of the whole environment which enables the totemic species to thrive.

Moreover, in prehistoric societies for example, totems were key symbols of religion and social cohesion (Smith, 1889; Frazer, 1887); they were also important tools for cultural and educational transmission. According to Sylvio \& Yahaya (2007), totemism plays a significant role in community bonding, but few scholars have examined its role in the development of environmental protection. In most traditional African cultures, it was illegal to kill or harm a totem. It was likewise illegal for a relative such as wife, who may have hailed from a different tribe and therefore had a different totem, to hurt the totem of a husband or son. This was mainly because totems were viewed as part of the kindred, and it was believed that these totems shared blood with the ancestors. To hurt a totem however, was tantamount to hurting the community's ancestors. Severe punishments, such as banishment, fines, hard labor, or death, were applied to anyone who disrespected their totem.

Besides these, many species are important to human welfare. They are not only standing in place to be venerated (Giddens, 2001), but play prominent role in crops production such as wild plants that are relatives of agricultural crops, or animals that are harvested for human consumption as well as some species of animals and plants (such as earthworms, bees, and termites among others) which help to maintain a healthy and productive ecosystem (Johns, 1992). An outright elimination of this species disrupts the ecological flows.

Relatively, totemism can lead to environmental protection due to the fact that many tribes have multiple totems and it is a taboo to eliminate them, thus prevent species' extinction. For example, over 100 plant and animal species are considered totems among the Batooro (omuziro), Banyoro and Baganda (omuzilo) tribes in Uganda; a similar number of species are considered totems among tribes in Congo (DRC) and the Central African Republic (CAR). Totems identify the different clans among the Shona that historically made up the dynasties of their ancient civilization. Today, up to 25 
different totems can be identified among the Shona, and similar totems exist among other South African groups, such as the Zulu, the Ndebele, and the Herero (Sylvio \& Yahya, 2007).

\section{Totemism as an Indigenous Environmental Conservation Practice}

The practice of totemism is as old as the history of man. Thus, exemplifies its non-western practice most especially among the people of Africa and some of the third world countries of the world. Among the Wiradjuri, an Aboriginal people for example, who traditionally lived in New South Wales (NSW), Australia, the practice of totemism was documented. In its practice individual totem belong only to the medicine men and are passed on patrilineally. Such an individual totem is named bala, 'spirit companion', or Jarawaijewa, 'the meat (totem) that is within him." In this however, there is a strict prohibition against eating the totem. Breach of the taboo carries severe sanctions with it sickness or death.

Similarly, among the Nor-Papua of Guinea, patrilineal, exogamous groups (consanguineous sibs) fish was found as totem. Totem animals are represented in various manifestations such as spirit creatures in sacred flutes, in disguises, and in figures preserved in each man's house (Haekel, 2013).

The Iban of Sarawak, Malaysia is not exempted in the practice of totemism. Here, individual totemism has been the tradition. The Iban observe the mannerisms of animals and recognize them in the behaviour of the animals the embodiment of their protector spirit (ngarong). Thus, becomes an element of taboo to harm, kill or eat by the Iban (Haekel, 2013).

The people of Birhor, who were traditionally residents of the jungle of Chota Nagpur Plateau in the Northern Decan (India), are equally organized into patrilineal, exogamous totem groups. In Bihor, different groups are identified with different totems which apparently form the basis of their bonds as well as promoting environmental preservation. The totems are significant to the people of Bihor not only to their physical environment but help to pass tales about the divergent tribe's origins from one generation to another. As such, prohibitions or taboos are sometimes cultivated to an extreme degree in regard to eating, killing, or destroying them so as to prevent the wrath of the totem (Haekel, 2013).

The Kpelle people of Liberia also practice totemism. To them totems are referred to as things of possession, things connected to birth, or things of the back of men. These however express the idea that the totem always accompanies, belongs to, and stands behind one as a guide and protector against dangers. Among the Kpelle people, any breach of totemic indoctrination attracts severe punishment (Haekel, 2013).

\section{The Case of Nembe}

Nembe is located in Bayelsa State, in the south-south geo-political zone of Nigeria. It serves as the headquarters of Nembe Local Government Area. Geographically, it is located on latitude 4034'49"N and longitude 6022'58'E. It has an area of $760 \mathrm{~km}^{2}$. 2006 Population Census puts the population of Nembe 130, 931. It is characterized by mangrove forest type of vegetation and located very close to the Atlantic Ocean.

In terms of totemic beliefs among the Nembe people, multiple totems exist. According to Alagoa and Okorobia (2011) in spite of the enmity that God has put between the snake and the man, sequel to what happened in the Garden of Eden (Gen 3:15); the killing of python (a species of snake) is forbidden in the Kingdom. This is because any attempt to do so often attracts severe penalty or sanctions. As such the people of Nembe relate freely with Python (s) without getting hurt or harmed by the snake species.

According to Nengi James (cited in Alagoa and Okorobia, 2011), 'Ogidiga' is a name of a god in the kingdom, which was named after its priest, and metamorphosed into a python. The god (Ogidiga) is so dear to the people of the Nembe, having assisted in unifying all the clans that constitute the community through totemic ties and sanctions that they have outlawed on the killing of pythons. In addition to this, there exists zibaerema (royal), eagle (agbalakoko), shark among the Brass people as well as snail among fantuo people as totems in Nembe of which any attempt to kill, harm or eat them will invariably attract the wrath of the spirit of totem.

\section{Method and Procedures}

The study adopted descriptive research design. Three hundred and eighty two (382) respondents participated in the quantitative aspect of the study using an instrument of questionnaire as well as 5 key informants' interviewees using an instrument of interview. Considering the nature of the study area, stratified random sampling was employed in the selection of respondents for the quantitative aspect of the study while purposive sampling technique was used for the qualitative aspect of the study. 
In an attempt to select respondents in the study locale, the people of Nembe was stratified based on the communities that constitute them (Ogbolomabiri, Basanbiri, Odeama, Okpoama and Brass). Thereafter selection of individual participants above the age of 15 years was carried out on the basis of clans, compounds and families at random with respect to families' composition in each of the compounds. So also, in the process of engaging respondents in the study, their consents to participate were sought as well as assuring them of their anonymity and confidentiality of the autonomous decisions made in answering the questions administered to them and interview conducted respectively.

\section{Results and Discussions}

Data collected for the study were analyzed based on the instruments employed for the data collection. For the questionnaire, simple percentage in a table-format analysis and charts were used for the analysis using Microsoft Excel while content analysis method was employed for the key informants' interviews conducted. However, two categories of questions were asked from respondents, namely: socio-demographical information and questions related to totemic belief and environmental preservation. The following table and charts illustrate the presentation and analysis of the data.

\section{Socio-Demographical Characteristics of the Respondents}

Table 1: Percentage Distribution of Respondents By Socio-Demographic Characteristics

\begin{tabular}{|c|c|c|}
\hline Categories of Respondents & Frequencies & Percentages \\
\hline Sex & 382 & 100 \\
Male & 214 & 56 \\
Female & 168 & 44 \\
\hline Age & 382 & 100 \\
$15-20$ & 103 & 27.0 \\
$21-25$ & 84 & 22.0 \\
$26-30$ & 95 & 24.9 \\
31 and Above & 100 & 26.2 \\
\hline Religion & 382 & 100 \\
Christian & 258 & 67.5 \\
Islam & 3 & 0.8 \\
Catholicsm & 96 & 25.1 \\
ATR & 25 & 6.5 \\
\hline Occupation & 382 & 100.0 \\
Farming/Fishing & 187 & 49.0 \\
Trading & 93 & 24.3 \\
Civil Servants & 46 & 12.0 \\
Others & 56 & 14.7 \\
\hline Educational Attainment & 382 & 100 \\
Primary & 33 & 8.6 \\
Secondary & 147 & 38.5 \\
Tertiary & 86 & 22.5 \\
Drop out & 57 & 14.9 \\
Others & 59 & 15.4 \\
\hline
\end{tabular}

Source: Field Data, 2013

As depicted on table 1, the larger percentage of respondents (participants) was male represented by $56 \%$ (214), while female's percentage was $44 \%$ (168). This implies that the male participants in the study are more than the females which did not have much significant to the findings of the study. So also in the study, the age range of the participants from 15 20 is represented by $27 \%, 21-25(22 \%), 26-30(24.9 \%), 31$ and above $(26.2 \%)$, while the average age of participants is 31. This shows that all participants in the study are adults who have been thoroughly socialized into the norms and values of the research locale.

In terms of the religion practice in the entire domicile of the study, $90.3 \%$ of respondents practice Christianity, $2.9 \%$ Islam, 6.8\% African Traditional Religion (ATR). This shows that despite the practice of diverse religion and minimal percentage practicing ATR (6.8\%) as a religion, respondents still give much recognition to python as a taboo that must be 
venerated, not to be killed, harm or eaten. On the other hand, and in terms of occupational engagements of the participants of the study, $49 \%$ of the respondents engaged in farming/fishing, $24.3 \%$ trading, $12 \%$ civil servants, while other occupational engagements of the respondents including the students is $14.7 \%$. This indicates that the largest percentage of the respondents in the study represented by farming/fishing would in one way or the other be familiar to the subject of the study if at all other participants may not be familiar with the subjects of the study.

On the educational attainment of the respondents, $8.6 \%$ of them attended primary school, $38.5 \%$ secondary education, $22.5 \%$ tertiary, $14.6 \%$ drop outs, while other categories of educational attainment represented by $15.4 \%$ attended neither categories of education listed, but may be apprentice or otherwise. This shows that at least $38.5 \%$ of the respondents have secondary education, an indication that the level of illiteracy among the participants in the study is at minimal. This also implies that the respondents are well informed of the practice of the subjects of investigation of the study (totemic belief).

Fig.1. Percentage Distribution of Respondents by the Awareness of the Practice of Totemic Belief

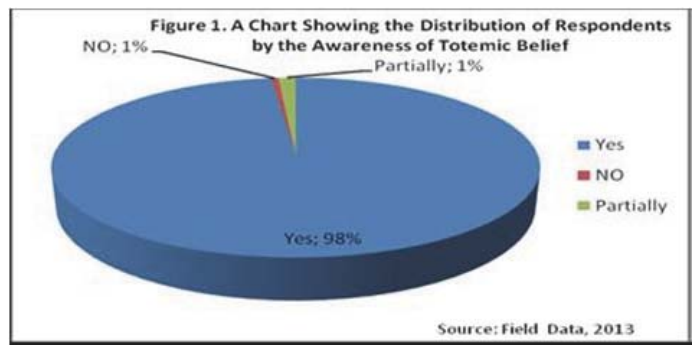

Figure 1 . shows that $98 \%$ of the respondents are aware of the practice of totemism, $1 \%$ said No, while $1 \%$ said partially. This implies that almost all the people in the study area are aware of totemic belief.

Fig. 2. Percentage Distribution of Respondents by the Species Regarded as Totems

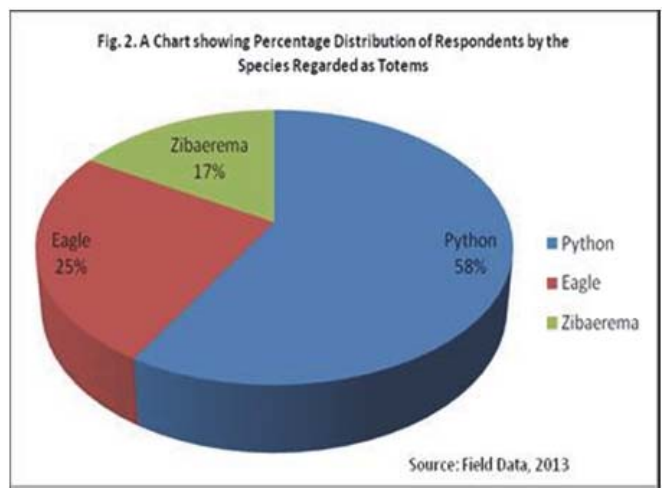

As indicated on fig. 2., the largest percentage of the respondents (58\%) said python is regarded as totem, $25 \%$ of them said eagle, while $17 \%$ said zibaerema (royal). This implies that both animals: python, eagle and zibaerema are regarded as totems in the study area. In confirmation of the responses from the empirical analysis, a participant from key informant interview has this said:

As far as I am concerned in this community, there is nobody that does not know that python is not a totem which must not be killed..... I can also say eagle is a totem that we don't kill. So also, zibaerema even shark in water. But python is the most well known snake regarded as totem because it is used to represent the god of ogidiga in Nembe (KII/Male Participant). 
Fig. 3. Percentage Distribution of Respondents by Social or Health Sanctions if the any of the Species Regarded as a Totem Killed

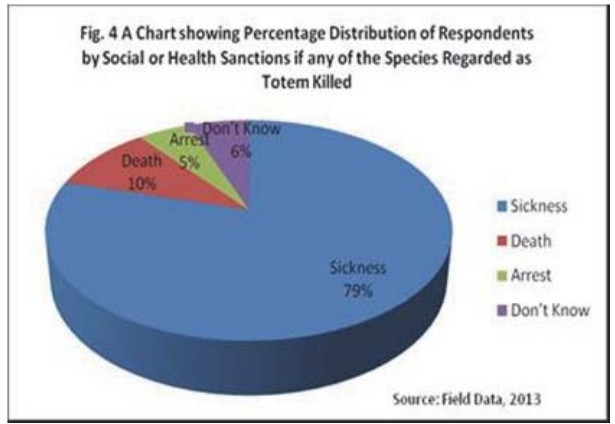

As indicated on fig. 3,79\% of the respondents said if any of the species regarded as totem is killed 'sickness' will be inflicted on the person, $10 \%$ said death penalty, $5 \%$ said arrest while the remaining respondents $6 \%$ said they don't know any social or health sanction if any of the species regarded as a totem in the study area is killed. This implies that the largest percentage of the respondents reprensented by $79 \%$ agreed that sickness is the penalty to any one who killed species of animal regarded as a totem. This is however elaborated by the statement of a participant in the key informant interview conducted:

The major sanction is the health of the person that kills or harm any of the totems particularly python. This is because nobody will arrest him except if an elderly person is there to caution the person that kills it, but the person may be asked to go and appease the god of the python (ogidiga) if not...Although if the killing of such totem is not taken care of by the priest of ogidiga by appeasing the god, it may eventually lead to the death of the killer. Therefore, it is very dangerous to kill any of the totem in this community (KII/Male Participant).

\section{Percentage Distribution of Respondents by the Threats Posed to Humans if Species Regarded as Totem are not Eliminated}

As Shown on fig. 4, $73 \%$ of the respondents said the act of not killing some species of animals regarded as totems pose danger to the livestock in the study area, $21 \%$ of them said, it poses danger to farmers, while $6 \%$ of them said it poses danger to human life. This implies that though they serve as totems to the study area but they elicit some levels of threats most especially to their livestock as indicated by the largest percentage of respondents (73\%) followed by $21 \%$ of the respondents who said they posed threats or danger to human life. To give more illustration on this, participants from the key informant interviews conducted had this said:

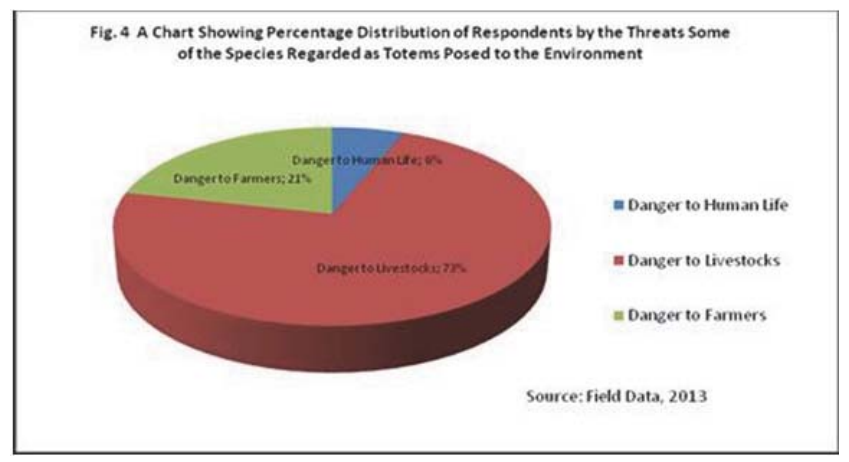

I will not say Ekekoru do not pose a threat to our livestocks, but not every time. The reason being that we are somehow confused of Ekekoru, the actual species that represents Ogidiga, with Odunmo another species of python which is more dangerous than Ekekoru, the one we actually forbid. But due to our people not to get confused of the Ekekoru with Odunmo, because they look similar we just have to forbid all the species of python in our land so that we will not 
provoke the god of our land, the Ogidiga by mistakingly kiling Ekekoru (KII/Male Participant).

...The issue of Ekekoru you are talking about kill our chicken and eat up their eggs some times, most especially those of us that stay close to the creeks and forest areas in this community. In fact, there was a time I got confused of the snake. Because if you harm or kill it you yourself will see the repercussions from the god of Ogidiga, that is the problem will have with Ekekoru.... I don't know about other ones like eagle or shark but I about python (KII/ A Female Participant).

Fig. 5. Percentage Distribution of Respondents by the Environmental Preservation Significance of the Species of Animal Regarded as Totems

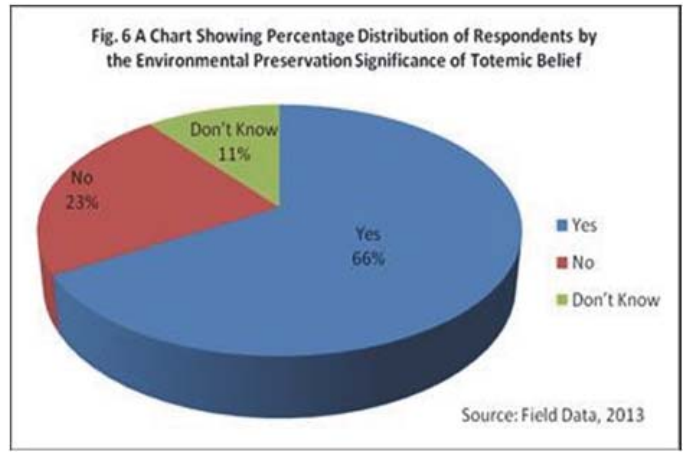

Fig. 5 shows that $66 \%$ of the respondents said Yes as to the environmental preservation significance of the species of animals regarded as totems in the study area, $23 \%$ said No, while $11 \%$ of the respondents said Don't know. This implies that the largest percentage of the respondents (66\%) who said yes as to the environmental preservation significance of animals regarded as totems in the study area agreed to the fact that totemic belief promotes environmental preservation.

Fig. 6. Percentage Distribution of Respondents by their Suggestions in Promoting Totemic Belief

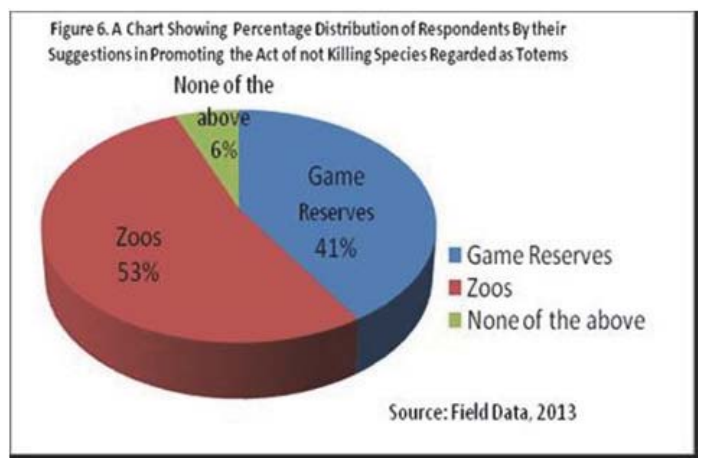

Fig. 6 Shows that $53 \%$ of the respondents suggested the provision zoos in order to promote the act of not killing species regarded as totems in the study area, $41 \%$ suggested game reserves, while $6 \%$ of the respondents were not in support of any of the two stated: zoos and game reserves. This invariably implies that the largest percentage of the respondents are in support of the government in making provisions for zoos as indicated by $53 \%$ followed by $41 \%$ who suggested game reserves in the study area. As such, the least percentage of respondents who do not subscribe to any of the suggestions that will promote the act of not killing species of animals regarded as totems in the study area is thus insignificant to the findings of the study.

\section{Summary of Findings}

Based on the objectives of the study, the following are the summary of findings of the study: 
- That the practice of totemism exists in the study area as indicated on fig. 1 which is equally exemplified by fig.2 that there exist the species of python, eagle, shark, snail and zibaerema regarded as totems.

- That any attempt to violate the killing, harm or outright elimination of the species of animals regarded as totems, there exist social sanctions or health problem that would be inflicted on the violator as depicted on fig.3.

- That the act of not killing some species of animals regarded as totems posed some levels of dangers to humans and livestock as indicated on fig. 4.

- That the act of attaching totemic beliefs to some species of animals promotes environmental preservation as indicated on fig. 5.

\section{Conclusion and Policy Implications}

It is quite obvious in the view of the findings of the study that there are indigenous practices in the study area that stand to promote environmental preservation with minimal cost on the part of government to implement and execute environmental laws that are in most cases seem to be challenging the people at the grassroots. In other words, a plethora of rich cultural practices exist not only in the study area but Africa countries at large that if properly harnessed and applied to environmental conservation practices, species extinction and other environmental predicament orchestrated by human activities would be reduced to the bearest minimum thereby creating rooms for environmental preservation as well as preserving species of animals for both present generation and the generations to come.

In the view of the findings of this study, the government and relevant agencies on environmental issues should not in any way ignore some of the indigenous practices (such as totemism) that stand to be very beneficial to the promotion of environmental conservation. In this however, the following are the policy implications of the study:

- The government should design environmental policies that would urgently facilitate the establishment of zoos and game reserves in communities where wildlife serve as totem at the same time pose some levels of threats to humans and livestock so that species of animals that serve as totems can be taken to zoos and game reserves. This will help to reduce the danger they may elicit to the social environment as well as preventing them from extinction.

- Policies that would promote research on indigenous practices which stand to promote environmental preservation across diverse cultures should be as a matter of urgency formulated by the government so as to prevent species extinctions as well as the escalation of environmental related problems.

- Government should embark on sensitization and enlightenment campaigns that would be educative enough to unveil the 'hidden cultural practices' that stand to promote environmental preservation across the country.

- Apart from the indigenous measures of wild life conservation, other natural measures of environmental preservation that would be sustainable should be adopted by all and sundry. Such may include planting of trees to replace the ones cut for domestic or industrial use or fishing without the use of chemicals and so on.

\section{References}

Alagoa, E. and Okorobia, A. (2011). Nembe 'Se' Congress: A Study to the United Approach to Development in Nembe 'Se'. PortHarcourt; Onyoma Research Publications.

Attfield, R. (1983). The Ethics of Environmental Concern. Oxford, UK, Basil Blackwell.

Blumer, H. (1969). Symbolic Interactionism; Perspective and Method. Englewood Cliffs, NJ: Prentice-Hall

Charles, J. (2005). Sociological Theory: A Historic-Analytic Approach on Man and Society. Lagos; Serenity Printing and Publishing Co.

DeRosso Deb (2003). The Structural Functional Theoretical Approach, [1] www.wisc-online.com/objects>Accessed February 24, 2012

Durkheim, E. (1912). "The Elementary Forms of Religious Life". [Excerpt from Robert Alun Jones. Emile Durkheim: An Introduction to Four major Works. Berverly Hills, CA: Sage publications, Inc., 1986. Pp. 115-155.].

Elkin, A. P., (1933). "Studies in Australian Totemism". Oceania Monographs, No.2, Sydney (Oceania, Vol.III, Nos. 3 and 4; Vol.4, Nos.1 \& 2)

Elkin, A.P.,(1954). (1st ed. 1938), The Australian Aborigines: How to Understand Them. Angus \& Robertson, Sydney

Giddens, A. (2001). Sociology 4th Edition. Oxford UK; Blackwell Publishers Ltd.

Haekel, J. (2013). Totemism (Religion). In: Encyclopedia Britannica (http://www.britannica.com/EBchecked/topic/600496 Itotemism/38114/Nor-PapuaRetrieved 16/04/2013)

Igbo E.M. (2003). Basic Sociology. Enugu; CIDJAB PRESS.

James F. (1887). Totemism. Edinburgh; A \& C Black

Jeremy T. Kerr and Isabelle Deguise (2004). "Habitat Loss and the Limits to Endangered Species Recovery". Ecology Letters.vol. 7 
issue $12 \mathrm{pg}$ 1163-1169.

Johns, A. D. (1992). Species Conservation in Managed Tropical Forest. In: Whitmore, T. C. and Sayer, J. A. (eds). Tropical Deforestation and Species Extinction. London; Chapman \& Hall pg. 15- 50.

Liadi, O. F. (2013). Symbolic Interactionism Perspective in Sociological Explanations. In: Olutayo, A.O \& Akanle (eds). Sociological Theory for African Students. First Edition.Ibadan. Ibadan University Press. Pg. 149-159.

Macionis G. (2010). Sociology 7th Canadian Ed. Pearson Canada Inc.

Meltzer B.N., Petras J.W. \& Reynolds L.T.(1975). Symbolic Interactionism: Genesis, Varieties, and Criticism. Boston: Routledge and Kegan Paul.

Mitchell, R.B., (2003)."International Environmental Agreements: A Survey of Their Features, Formation, and Effects". Annual Review of Environment and Resources. p. 429-429-461.

Schweitzer, A. (1923). Civilization and Ethics. J. Naish (trans.).London, A \& C

Solomon, U., (2010). A Detailed Look At The Three Disciplines, Environmental Ethics, Law And Education To Determine Which Plays The Most Critical Role In Environmental Enhancement And Protection. Environment, Development and Sustainability, 2010. 12(6): p. 1069-1080

Sylvio, G. C. \& Yahya E. (2007). "Totem". In Encyclopedia of Earth. (Washington, D.C.: Environmental Information Coalition, National Council for Science and the Environment). <http://www.eoearth.org/article/Totem> Retrieved April 23, 2013.

Taylor, P. (1986). Respect for Nature: A Theory of Environmental Ethics.

Urry, J. (2000). "Metaphors". Sociology Beyond Societies: Mobilities for the twenty-first century. Routledge. p. 23. ISBN 978-0-41519089-3.Vol. 11, pp. 71-83.

\section{Footnotes}

- United Nations Conference on Environment and Development Agenda 21:The Key Documents of the United Nations Environment Protection (UNEP) Declaration (www.unep.org).

- UN -Species and Ecosystems: Resources for Development -Chapter 6 (http:www.un-documents.net/keys.htm) 